\title{
Hintereisferner, Austria: mass-balance reconstruction and numerical modelling of the historical length variations
}

\author{
W. GREUELL \\ Geographisches Institut, Eidgenössische Technische Hochschule, CH-8057 Zürich, Switzerland
}

\begin{abstract}
In this study, an attempt is made to simulate the historical length variations of Hintereisferner (Austria). Key elements in the model are: (1) reconstruction of the local climate (Vent); (2) multiple linear regression analysis between measured climate and mass-balance variations; (3) reconstruction of the mass balance with (1) and (2); (4) a one-dimensional numerical ice-flow model forced by the mass-balance history. Progress relative to the previous, similar studies can be summarized as two points: (1) the mass balance is reconstructed more carefully, and (2) sensitivity experiments show that uncertainties and assumptions in the flow model hardly affect the response of the glacier to climate fluctuations with a time-scale of the order of (or larger than) the response time of the glacier (around 100 year).

In the regression equation, mass-balance fluctuations are determined by the temperature during the ablation season and the annual precipitation. Cloudiness has no effect. The local temperature can be reconstructed as far back as 1755 with the temperature series from Basel, but the reconstruction of precipitation is unreliable prior to 1900. Mainly due to this point, a simulation starting in 1755 failed completely. However, in a run starting in 1894 , the total retreat since then $(2.2 \mathrm{~km})$ was reproduced within $10 \%$.
\end{abstract}

\section{INTRODUGTION}

This paper deals with historical glacier-length variations and their relation to climatic change. Length variations have been treated extensively in the literature (e.g. Wilhelm, 1975; Patzelt, 1985; Porter, 1986; Oerlemans, 1988; Greuell, 1989). In the Alps, the general picture is a retreat during the last century but, in fact, data from other regions indicate that this behaviour is of a worldwide nature.

If almost all glaciers advance or retreat at the same time, the cause must be of a climatic nature. The relation between climate and glacier fluctuations has been discussed in the cited literature. In this study, an attempt is made to perform a numerical simulation of the historical length variations of a single glacier, Hintereisferner, starting from climatic records. Whilst doing so, we can learn a lot about the relevant physical processes and, if the simulation is successful, this is an indication that the physical processes are correctly described in the model.

The flow diagram in Figure 1 outlines the whole simulation. The two main parts are a reconstruction of the mass-balance history and the redistribution of the mass by means of an ice-flow model. The one-dimensional ice-flow model will be introduced in section 3. In section 4, some experiments showing the sensitivity of the simulation to uncertainties and assumptions in the flow model will be discussed. The mass balance has been measured only since 1952. So, it had to be reconstructed for the period before that. For this aim, a regression equation will be established from the mass balance and the climatic data measured during the period from 1952 onwards (section 5). The climatic data are those from Vent, a village about $10 \mathrm{~km}$ northeast of Hintereisferner. As these data do not go back in time as far as desired, they will partly be reconstructed by means of climate series from other stations. Substitution into the regression equation then leads to the reconstruction of the mass-balance history (section 6). Finally, the results of the simulations will be treated (section 7).

So far, only a few attempts have been made to do studies similar to the present one. Oerlemans (1986) simulated the historical length variations of Nigardsbreen

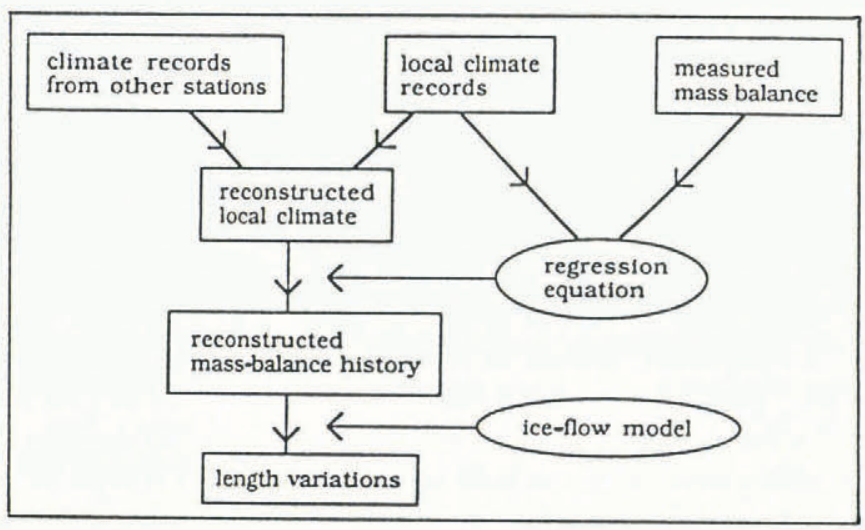

Fig. 1. Flow diagram of the simulation. 
(Norway), Stroeven and others (1989) made a study of Rhonegletscher (Switzerland) and Huybrechts and others (1989) investigated Glacier d'Argentière (French Alps). Compared to this study, these authors essentially used the same flow model but their approach in reconstructing the mass-balance history was somewhat different.

Their results are generally poor. The authors blamed this on inadequate knowledge of climatic series and/or the use of a poor relationship between climate and massbalance variations. They agreed that their failure to simulate the retreat during the last century, and other movements with a similar time-scale, cannot be due to inadequacies in the flow model. This last point will be checked in a systematic way in section. 4 . In view of the conclusions from these studies, more attention will be paid here to the reconstruction of the mass-balance history.

An extended version of this paper has already been presented by Greuell (1989).

\section{HINTEREISFERNER}

Hintereisferner and its main tributaries, Langtauferer-

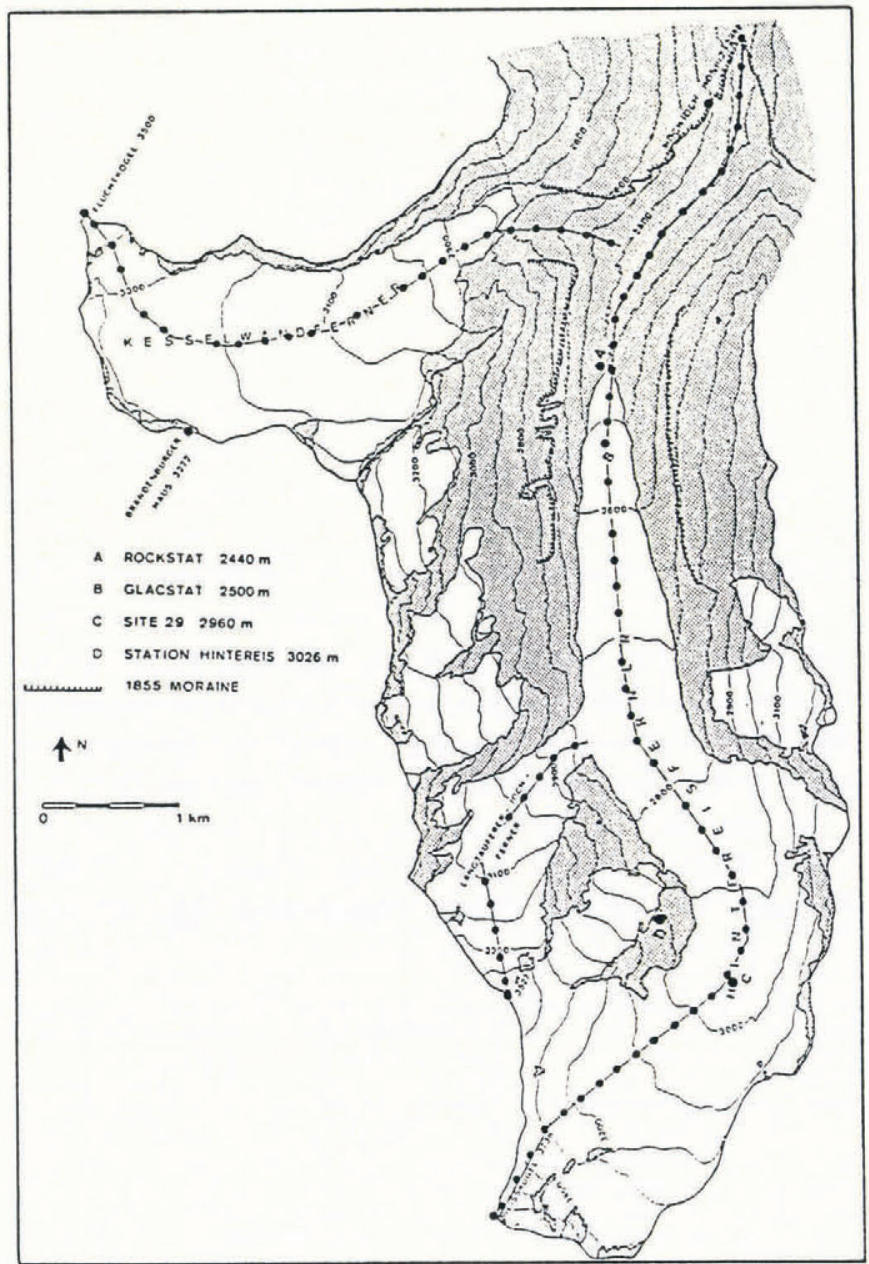

Fig. 2. Catchment area of Hintereisferner and Kesselwandferner. White areas were glacierized in 1969. Since then $A, B, C$ and $D$ are the locations of climatological and energy-balance stations. Flowlines are indicated and grid points are

Hintereisferner retreated so far that the terminus was about midway between GLACSTAT and ROCKSTAT in 1986.

marked by dots.
Table 1. Topography of Hintereisferner (including Langtaufererjochferner) and Kesselwandferner (data 1979)

Hintereisferner Kesselwandferner

$\begin{array}{lcc}\text { Length } & 7.4 \mathrm{~km} & 4.4 \mathrm{~km} \\ \text { Head } & 3730 \mathrm{~m} & 3490 \mathrm{~m} \\ \text { ELA } & & \\ \text { (mean 1966-81) } & 2950 \mathrm{~m} & 3100 \mathrm{~m} \\ \text { Terminus } & 2450 \mathrm{~m} & 2630 \mathrm{~m} \\ \text { Surface area } & 9.1 \mathrm{~km}^{2} & 4.4 \mathrm{~km}^{2} \\ \text { Exposure } & \text { east-northeast } & \text { south-southeast }\end{array}$

jochferner and Kesselwandferner, are situated in the Oetztal Alps, Austria $\left(46^{\circ} 50^{\prime} \mathrm{N}, 10^{\circ} 50^{\prime} \mathrm{E}\right)$. An impression of the topography can be obtained from Figure 2 and Table 1. Below about $3000 \mathrm{~m}$, the main glacier consists of one branch and it flows in a slowly bending, regularly shaped valley. The surface slope is rather uniform with a maximum of about $10 \%$ near $3.8 \mathrm{~km}$ (measured from the top) and a minimum of about $4 \%$ near $4.6 \mathrm{~km}$. These characteristics make this part of the glacier rather suitable for the one-dimensional ice-flow model to be used in this study. In the upper area, the situation is less favourable. There, the glacier consists of several branches separated by ridges covered with ice.

At present (1988), Hintereisferner has one major tributary, Langtaufererjochferner, but its actual ice flux into the main stream is estimated to be very small. It has a length of about $2.4 \mathrm{~km}$, a surface area of about $2.1 \mathrm{~km}^{2}$ and the average slope is much larger than that of the main stream.

Kesselwandferner has an average slope of about $11 \%$ along the flowline between 0.4 and $3.1 \mathrm{~km}$. Nowadays, it ends in an icefall.

Observed length variations of Hintereisferner (Fig. 3) begin in 1847 . In 1855, the maximum observed length was reached. Thereafter, the glacier began a continuous retreat ( $2950 \mathrm{~m}$ until 1987$)$, that was only interrupted by the advance between 1917 and 1922 ( $85 \mathrm{~m}$ in total). According to a lichenometric study (Beschel, 1950), Hintereisferner had another maximum stand around $1770,60 \mathrm{~m}$ down-valley from the 1855 maximum stand. This relatively great length before 1855 , as well as the behaviour thereafter, makes Hintereisferner a good representative of large valley glaciers in the Alps.

Observations for Kesselwandferner are sparser and start in 1905 . This glacier also retreated considerably ( $550 \mathrm{~m}$ between 1905 and 1987) but two advances interrupted this trend (1914-20 and 1965-83). In 1905 and between 1920 and 1922(?), Kesselwandferner discharged into Hintereisferner. Data for Langtaufererjochferner are not available but this tributary probably always discharged into the main stream, since at least 1855 .

Vast amounts of field work have been carried out on Hintereisferner and Kesselwandferner (for summaries see Greuell (1989); Kuhn and others (unpublished)). No other glacier in the Alps could compete with Hintereisfer- 


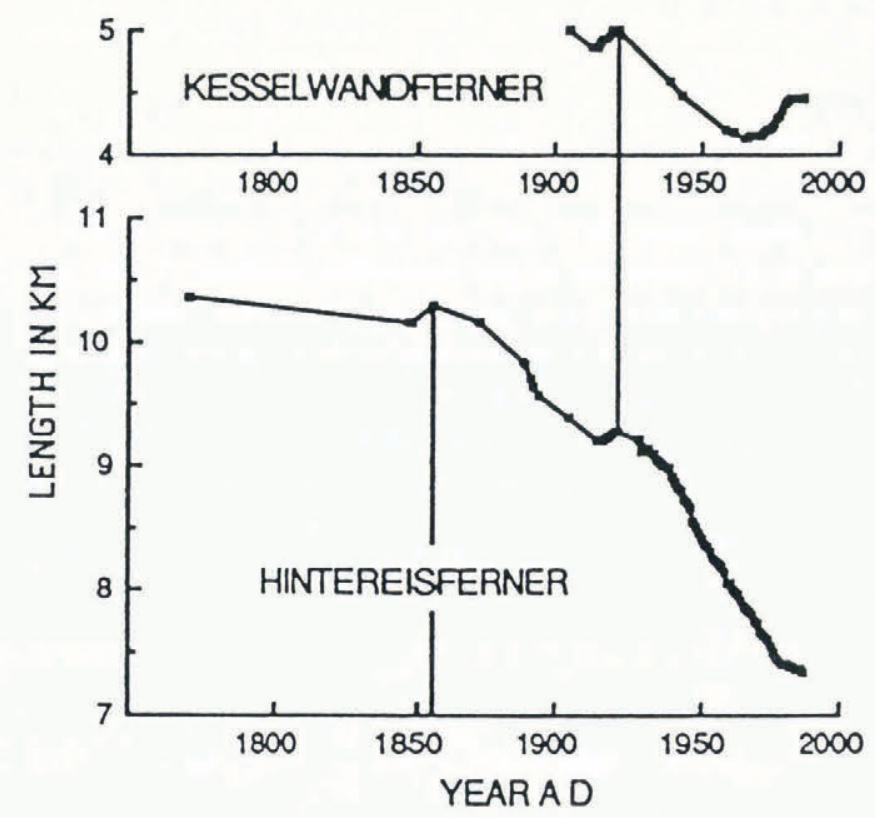

Fig. 3. Historical length variations of Hintereisferner and Kesselwandferner (data kindly provided by G. Patzelt, and from Kuhn and others, 1985). Each point corresponds to an observation.

ner on this point. For this study, intensive use was made of some of the maps, the mass-balance data, the climatic data from Vent and the velocity and ice-thickness measurements.

\section{THE FLOW MODEL}

\subsection{Introduction}

In this section the one-dimensional flowline model will be described. The description consists of three elements: the parameterization of the three-dimensional geometry, the continuity equation and the calculation of ice velocities. For the last element, it was desirable to calculate the basal water pressure and the longitudinal deviatoric stress. The model is forced by the mass balance which will be described in section 5 .

\subsection{Geometry and continuity equation}

Although the model is basically one-dimensional, the three-dimensional geometry is implicitly taken into account by the parameterization of the cross-sectional geometry at each grid point. The shape of the bed is

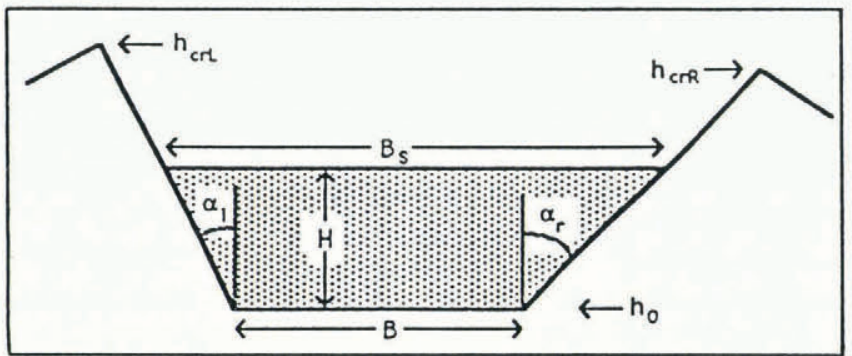

Fig. 4. Parameterization of the cross-sectional geometry. determined by six parameters (see Fig. 4): the elevation of the glacier bed $\left(h_{0}\right)$, the width of the valley bottom $(B)$, the angles of the slopes at the right $\left(\alpha_{\mathrm{R}}\right)$ and left $\left(\alpha_{\mathrm{L}}\right)$ sides of the valley, and the elevations of the crests at the right $\left(h_{\mathrm{crR}}\right)$ and left $\left(h_{\mathrm{crL}}\right)$ sides of the valley. These parameters were derived from maps and measured ice-thickness profiles (kindly provided by M. Kuhn). The measured profiles only cover that part of the main stream between $\mathrm{km} 2.0$ and the terminus. For the rest of the main stream and the tributaries, ice thickness was estimated from a constant driving stress, namely, the mean value from that part of the main stream covered by the measured profiles:

$$
\tau_{\mathrm{d}}=-\rho g H \mathrm{~d} h / \mathrm{d} x=1.4 \mathrm{bar} .
$$

The shape of the glacier itself is then determined by the bed geometry and the ice thickness $(H)$. This leaves us with a trapezoidal cross-section. The expression for the cross-sectional area of the glacier $(S)$ reads:

$$
S=\left[B+0.5\left(\operatorname{tg}\left(\alpha_{\mathrm{R}}\right)+\operatorname{tg}\left(\alpha_{\mathrm{L}}\right)\right) H\right] H .
$$

Because $H$ and $S$ are related through Equation (2), the rate of thickness change (the model output) can be obtained by solving the continuity equation expressed in $S$ :

$$
\frac{\partial S}{\partial t}=-\nabla \cdot[\bar{u} S]+\int_{W_{\mathrm{c}}} \frac{\partial m}{\partial t} \mathrm{~d} y
$$

where $\bar{u}$ is the cross-sectional mean velocity, $\partial m / \partial t$ the mass-balance rate, $y$ the horizontal direction perpendicular to the flowline and $W_{\mathrm{c}}$ the interface between the atmosphere and the glacier surface plus the adjacent slopes up to the crests. By computing the integral of the mass balance from crest-to-crest, the mass balance of the slopes above the glacier is taken into account. Mass balance is a function of elevation and time. The glacier ice is assumed to have constant density.

The grid-point distance is $200 \mathrm{~m}$ and the locations of the three flowlines modelled in this study are indicated in Figure 2. To solve the continuity equation, an explicit scheme is used with a time step of $1 / 40$ year. The massbalance rate is calculated only once a year.

\subsection{Calculation of the ice velocity}

The total velocity $(u)$ is the sum of the velocity due to internal deformation $\left(u_{\mathrm{d}}\right)$ and the sliding velocity $\left(u_{\mathrm{s}}\right)$. For the calculation of $u_{\mathrm{d}}$ and $u_{\mathrm{s}}$, the following equations are used (see Paterson, 1981):

$$
\begin{aligned}
& \overline{u_{\mathrm{d}}}=f_{1} \tau_{\mathrm{d}}{ }^{3} H \\
& \overline{u_{\mathrm{s}}}=f_{2} \frac{\tau_{\mathrm{d}}{ }^{3}}{(N-p)} \\
& \tau_{\mathrm{d}}=-\rho g H \frac{\partial h}{\partial x} \\
& f_{1}=0.4 s_{1}{ }^{3} s_{2} A .
\end{aligned}
$$

The bar denotes cross-sectional mean, $f_{1}$ and $f_{2}$ are flow parameters, $\tau_{\mathrm{d}}$ is the driving stress, $N$ is the overburden load, $p$ is the basal water pressure, $\rho$ is the ice density, $g$ is the acceleration due to gravity, $h$ is the elevation of the surface, $x$ is the coordinate in the length direction of the glacier, $s_{1}$ is the shape factor (see Paterson, 1981), $s_{2}$ is the 
ratio of the cross-sectional mean $u_{\mathrm{d}}$ to the vertically averaged $u_{\mathrm{d}}$ at the flowline and $A$ is the flow parameter in Nye's generalization of Glen's flow law.

The parameters $s_{1}$ and $s_{2}$ have been estimated by means of numerical calculations (Nye, 1965) and $A$ has been determined in the laboratory and by means of deformation measurements in the field (Paterson, 1981). However, values of $A$ vary by at least an order of magnitude, so that calculation of $f_{1}$ using Equation (7) would be highly inaccurate. We will see in the next section that by using $f_{1}$ (and $f_{2}$ ) as tuning parameters leads to much more accurate values.

\subsection{Basal water pressure}

The calculation of $p$ is a very precarious matter. This is certainly an important reason why in most studies $p$ is assumed to be zero or a constant fraction of $N$. Nevertheless, to have the possibility of testing the effect of non-zero water pressure on the glacier response, $p$ is calculated in this study using the model of Röthlisberger (1972). He assumed that the water at the bed concentrates itself into a single inclined, circular conduit (a so-called Röthlisberger conduit). The conduit is kept open by melting due to frictional heating by the running water. At the same time, the conduit tends to close under the overburden pressure minus the basal water pressure. In the analysis a steady state is assumed, resulting in the following equations (see Bindschadler, 1983):

$$
\begin{gathered}
\theta^{11 / 8}-0.316 \theta^{3 / 8} \frac{\partial p}{\partial x}= \\
D k^{-3 / 4} A_{\mathrm{w}} n^{-n} Q^{-1 / 4}(\cos \beta)^{-11 / 8}(N-p)^{n} \\
\theta=\frac{\partial p}{\partial x}+\rho_{\mathrm{w}} g \tan (\beta) .
\end{gathered}
$$

In these equations, $\theta$ is the force driving the water through the conduit, $D$ is a constant $\left(=3.63 \times 10^{10} \mathrm{~N} \mathrm{~m}^{-2}\right), Q$ is the water discharge through the conduit, $k$ is the roughness coefficient of the conduit wall, $\beta$ is the bed slope, $q_{\mathrm{w}}$ is the density of water, $n(=3)$ is the stress exponent in Nye's generalization of Glen's flow law and $A_{\text {w }}$ equals the flow parameter $A$ in the same law.

The roughness coefficient $k=10 \mathrm{~m}^{1 / 3} \mathrm{~s}^{-1}$ is adopted from Röthlisberger, $A_{\mathrm{w}}$ is used as a tuning parameter and the glacier profile provides values for $\beta(x)$ and $N(x) . Q(x)$ is fixed as the integral of the annual mean ablation rate over the glacier surface represented by the grid points between the glacier head and $x$. The annual mean ablation rate is estimated as the mass-balance rate minus an accumulation rate of $200 \mathrm{~cm}$ w.e. year $^{-1}$ which is independent of elevation. This leaves us with $p(x)$ as the only unknown variable. The numerical method used to solve the equations has been outlined in Greuell (1989).

Tuning was done with a longitudinal ice-thickness profile close to the actual (1988) profile of Hintereisferner. $A_{\text {w }}$ was chosen in such a way that the basal water pressure varied between 50 and $75 \%$ of the overburden pressure along the largest part of the glacier: $A_{w}=$ $95 \times 10^{-24} \mathrm{~m}^{6} \mathrm{~s}^{-1} \mathrm{~N}^{-3}$. This range was determined on South Cascade Glacier (Hodge, 1979) and might be typical for many non-surge-type glaciers. Basal water pressure has never been measured on Hintereisferner (personal communication from M. Kuhn).

\subsection{The longitudinal deviatoric stress}

The simulations were performed with the version of the flow model depicted in the preceding sections. Thus, the longitudinal deviatoric stress $\left(\tau_{x x}^{\prime}\right)$ was not taken into account. In section 4 , the sensitivity of the glacier response to the assumption $\tau_{x x}^{\prime}=0$ will be investigated. Computation of $\tau_{x x}^{\prime}$ will be done using a method developed by Van der Veen (1987). He solved the following three equations:

$$
\begin{aligned}
\frac{\partial u}{\partial z} & =A\left[\tau_{x x}^{\prime}{ }^{2}+\tau_{x z}{ }^{2}\right] \tau_{x x}^{\prime} \\
\frac{\partial u}{\partial z} & =2 A\left[\tau_{x x}^{\prime}{ }^{2}+\tau_{x z}{ }^{2}\right] \tau_{x z} \\
\tau_{x z}\left(z^{\prime}\right) & =-\rho g\left(h-z^{\prime}\right) \frac{\partial h}{\partial x}+2 \frac{\partial}{\partial x} \int_{z^{\prime}}^{h} \tau_{x x}^{\prime} \mathrm{d} z .
\end{aligned}
$$

Here $z$ is the vertical coordinate, which is positive upwards and zero at sea level, $\tau_{x z}$ is the shear stress and $h$ is the elevation of the surface. Equation (12) is substituted into the other equations and it is assumed that $\tau_{x x}^{\prime}(z)$ can be replaced by its vertical mean. The two resulting equations contain two unknown variables, namely $u_{\mathrm{d}}$ and $\tau_{x x}^{\prime}$. By eliminating $u_{\mathrm{d}}$, an equation for $\tau_{x x}^{\prime}$ can be derived which is then solved iteratively.

\section{SENSITIVITY EXPERIMENTS WITH THE FLOW MODEL}

We shall now investigate how the uncertainties and inaccuracies in the flow model could affect the historical simulations. Attention will be focused on the flow parameters $f_{1}$ and $f_{2}$, the ratio of the deformational to the sliding velocity and the assumptions of zero basal water pressure, and zero longitudinal deviatoric stress. It was felt that these are the items most liable to affect the model response.

The sensitivity experiments all follow the same procedure. They only deal with the main stream of Hintereisferner. As forcing the sum of a reference massbalance distribution $\left(m^{0} \mathrm{HEF}\right)$, only dependent on altitude, and an anomaly $(\mathrm{dm})$, dependent on time but not on altitude, is used:

$$
m_{\mathrm{HEF}}(z, t)=m^{0}{ }_{\mathrm{HEF}}(z)+d m(t)
$$

If not mentioned otherwise, the basal water pressure is taken into account and it is assumed that the longitudinal deviatoric stress is zero.

The first stage of each experiment is a tuning procedure. Several runs with, for example, different flow parameters are made until steady states using the 1979 length $(7.4 \mathrm{~km})$ are reached. Steady-state length is defined as the constant length asymptotically reached after imposing a fixed mass-balance distribution. As in this case, steady-state length is prescribed, $d m$ must be adjusted. The resulting longitudinal ice-thickness and velocity profiles are then compared to measured profiles (1979 for the thickness and the 1977-80 mean for the 
velocity). Note that real glaciers are never in a steady state! In this way it is possible to confine the range of possible values of $f_{1}$ and $f_{2}$, and it can be decided whether the calculations of $p$ and $\tau_{x x}^{\prime}$ are crucial or could possibly be omitted.

In the second stage, the response to a step change in the forcing is considered. Starting from the steady state achieved after the first stage, an extra mass-balance anomaly, that is independent of time and altitude, of $50 \mathrm{~cm}$ w.e. year ${ }^{-1}$ is imposed. The glacier then adjusts itself toward a new steady state. The responses of the different experiments are compared in terms of the length and volume-response times. These are defined as the time elapsed until $1-\mathrm{e}^{-1}$ of the total length (or volume) difference between the two steady states is bridged.

First, the values of $f_{1}$ and $f_{2}$ are considered. Three runs with different values of $f_{1}$ and $f_{2}$ were made (No. 1-3 in Table 2). Run 1 is the standard run $(f f=1.0)$. In run 2 , both $f_{1}$ and $f_{2}$ were halved $(f f=0.5)$, and in run 3 both $f_{1}$ and $f_{2}$ were doubled $(f f=2.0)$. The parameter $f f$ is defined as the ratio of the total velocity with the actual parameters and with the parameters used in the standard run. As the ratio of the deformational to the sliding velocity is not known, in the standard run $f_{1}$ and $f_{2}$ were chosen in such a way that this ratio was 1 when averaged over the grid points. This ratio changed only slightly during runs 2 and 3.

The three steady states with $L=7.4 \mathrm{~km}$ are compared between each other and using the measured data in Figures 5 and 6 in terms of ice thickness and velocity, respectively. Note that the velocity is not proportional to $f f$ due to different ice-thickness profiles. The standard run ( $f f=1.0$ ) seems to provide the best fit to the ice-thickness profile. For the velocity, the choice of a best fit is more dubious. In fact, the modelled cross-sectional mean velocity is compared with the measured surface velocity at the flowline. It is estimated that the latter should be reduced by a factor of $0.7 \pm 0.1$ to arrive at the crosssectional mean. Then, the best fit seems to be somewhere between $f f=0.5$ and 1.0 .

Combining the ice-thickness and velocity profiles, $f f=1.0$ seems to be the best choice. The associated values of $f_{1}$ and $f_{2}$ will therefore be used from now on. The range of uncertainty in $f f$ is estimated to be 0.3 , so $f f=1.0 \pm 0.3$. This value corresponds fairly well with those found in the studies mentioned in the introduction, namely 0.84 (Oerlemans, 1986), 0.83 (Stroeven and others, 1989) and 1.49 (Huybrechts and others, 1989).

Table 2. Sensitivity experiments. The effect of variations in $f_{1}$ and $f_{2}$ (runs 1-5), no calculation of the basal water pressure $(p=0$, run 6$)$ and the calculation of $\tau_{x x}^{\prime}$ $\left(\tau_{x x}^{\prime} \neq 0\right.$, run 7$)$ on the response times of Hintereisferner are investigated $\left(f_{1}\right.$ in $10^{-24} \mathrm{~m}^{6} \mathrm{~s}^{-1} \mathcal{N}^{-3}$ and $f_{2}$ in $10^{-16}$ $\left.m^{5} s^{-1} \mathcal{N}^{-2}\right)$

\begin{tabular}{|c|c|c|c|c|c|}
\hline \multirow{2}{*}{$\begin{array}{l}\text { Run } \\
\text { No. }\end{array}$} & \multirow[t]{2}{*}{$f_{1}$} & \multirow[t]{2}{*}{$f_{2}$} & \multirow[t]{2}{*}{ ff } & $\tau_{\mathrm{L}}$ & \multirow{2}{*}{$\begin{array}{c}T_{\mathrm{V}} \\
\text { year }\end{array}$} \\
\hline & & & & year & \\
\hline 1 & 0.851 & 1.028 & 1.0 & 94 & 78 \\
\hline 2 & 0.425 & 0.514 & 0.5 & 118 & 96 \\
\hline 3 & 1.702 & 2.056 & 2.0 & 82 & 64 \\
\hline 4 & 1.702 & 0.000 & 1.0 & 91 & 72 \\
\hline 5 & 0.000 & 2.056 & 1.0 & 95 & 83 \\
\hline 6 & 0.851 & 1.028 & $p=0$ & 107 & 88 \\
\hline 7 & 0.851 & 1.028 & $\tau_{x x}^{\prime} \neq 0$ & 95 & 74 \\
\hline
\end{tabular}

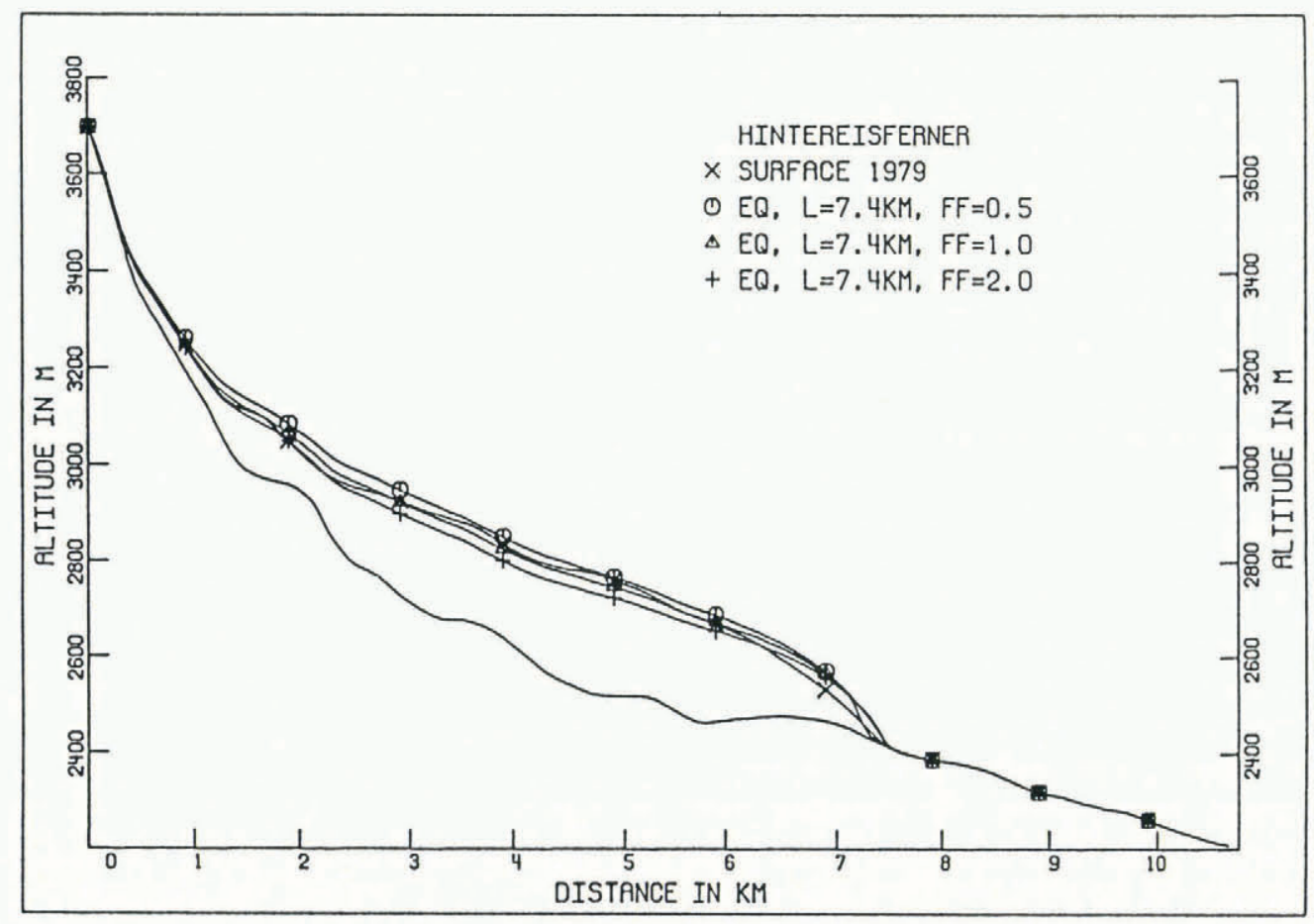

Fig. 5. Three steady-state ice-thickness profiles for a glacier length of $7.4 \mathrm{~km}$. They correspond to different values of the flow parameters $f_{1}$ and $f_{2}$ (see text) and are compared to the 1979 profile. 


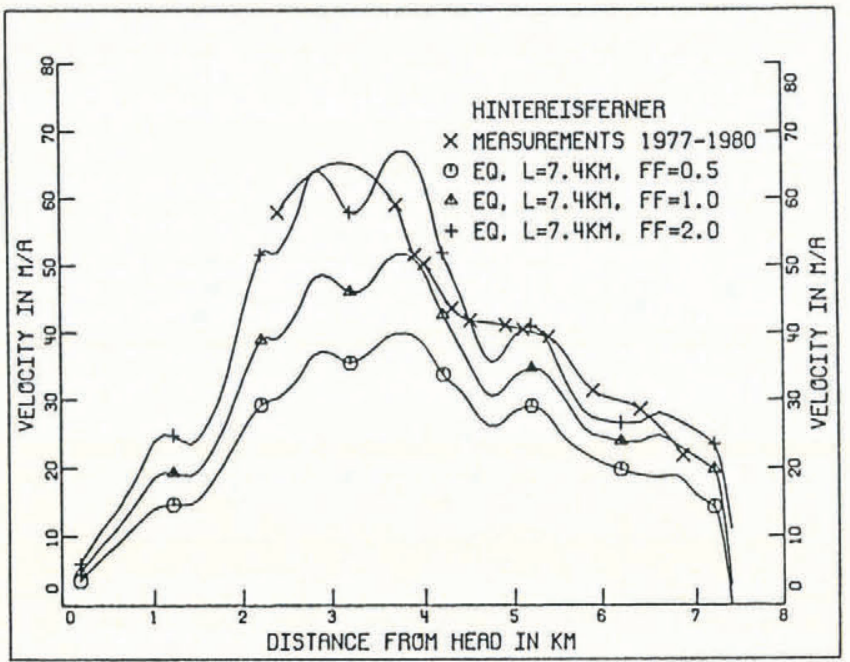

Fig. 6. As for Figure 5, but here velocities are compared. Note that the calculated velocities are cross-sectional means while the measurements (mean values for 1977-80) were taken at the surface near the flowline.

Figures 7 and 8 show the response in terms of length and volume, respectively, during runs 1-3 after imposing the extra mass-balance anomaly. The steps in Figure 7 are due to the limited resolution of the grid $(\Delta x=200 \mathrm{~m})$. Note (Table 2) that the length-response time is always larger than the volume-response time. A comparison of the different runs shows that changes in $f f$ have relatively little effect on the response times. While values of $f f$ differ by a factor of 4 between runs 2 and 3, the ratio of the response times is only 1.44 for length and 1.50 for volume. With a range of uncertainty in $f f$ of $\pm 0.3, T_{\mathrm{L}}=94 \pm 15$ year and $T_{\mathrm{V}}=78 \pm 10$ year.

In the preceding experiments, the ratio of the deformational to the sliding velocity was 1 , but it has never been determined for Hintereisferner in a systematic way. Therefore, to test the importance of the assumption concerning this ratio, two more runs were made (4 and 5 in Table 2). In run 4 , the sliding velocity is put equal to zero, while the deformational velocity is doubled, and in run 5 the deformational velocity is put equal to zero, while the sliding velocity is doubled. So, $f f=1.0$ in runs 1,4 and 5 . The steady-state thickness and velocity profiles corresponding to runs 4 and 5 are very similar to those corresponding to run 1 (see Figs 5 and 6). So, it is impossible to determine $\overline{u_{\mathrm{d}}} / \overline{u_{\mathrm{s}}}$ by tuning with the icethickness and velocity profiles. But, fortunately, the choice of this ratio has no significant effect on the response times (Table 2). Therefore, the values of $f_{1}$ and $f_{2}$ from run 1 were retained.

The effect of the calculation of $p$ on the model results was investigated by comparison of two runs: the standard run (run 1), performed with calculation of $p$, and run 6 , performed with the assumption $p=0$, but with the same $f_{1}$ and $f_{2}$. The velocities of the steady states with length $7.4 \mathrm{~km}$ are compared in Figure 9. As expected, the calculation of $p$ leads to higher velocities in most parts of the glacier. Apparently, the effect of the calculation of $p$ is roughly equivalent to a slight increase in $f f$ (cf. Fig. 6). Therefore, the assumption $p=0$ can be compensated for by a small increase in $f f$, so that in the simulations the

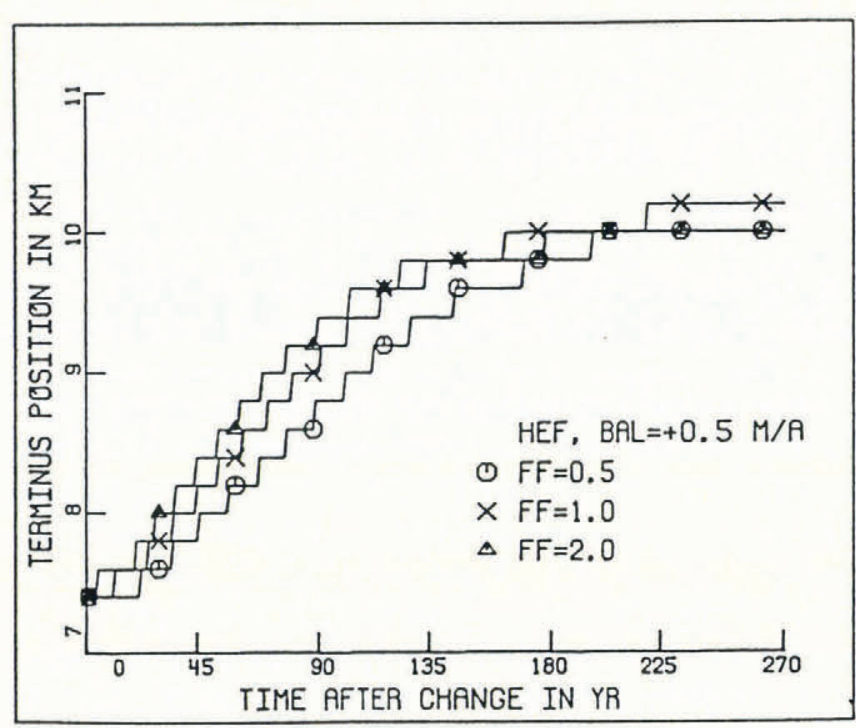

Fig. 7. Transition between two steady states in terms of glacier length. The three experiments correspond to different values of the flow parameters $f_{1}$ and $f_{2}$ (see text).

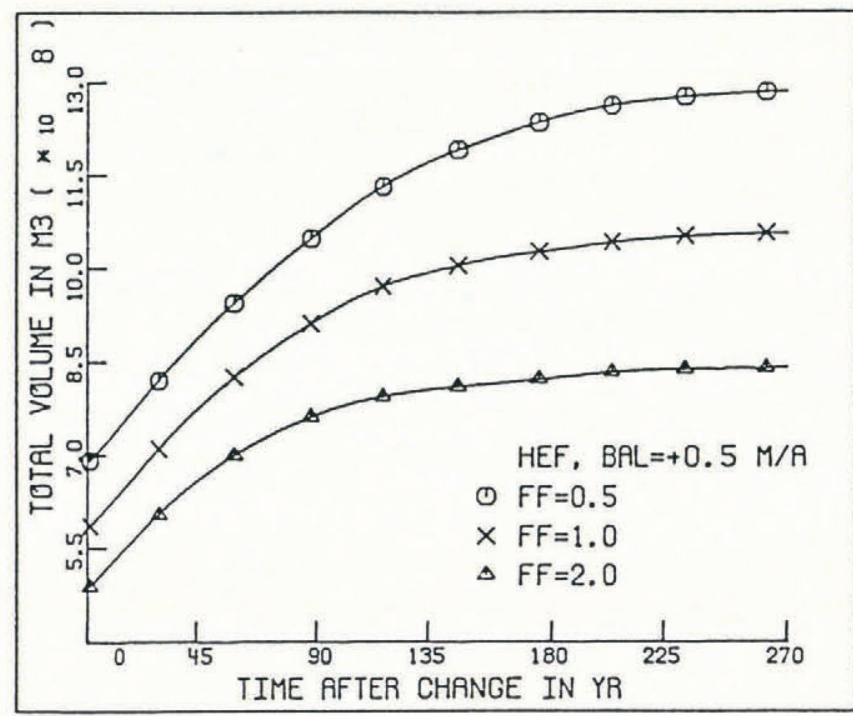

Fig. 8. As for Figure 7, but for glacier volume.

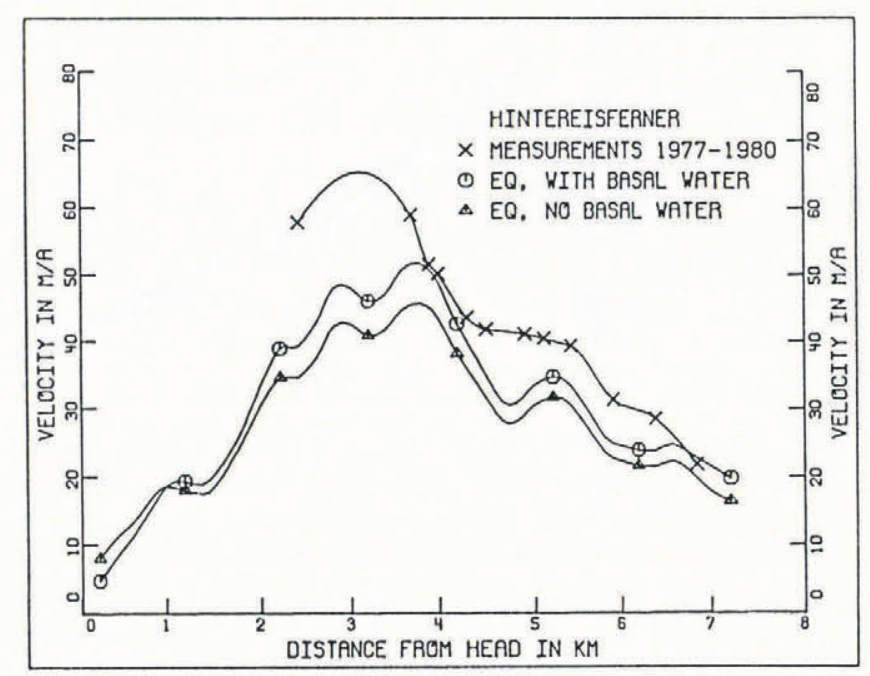

Fig. 9. As for Figure 6, but here runs with and without calculation of the basal water pressure are compared. 
calculation of $p$ can be omitted. As expected, the assumption $p=0$ causes a small increase in the response time of the glacier: $T_{\mathrm{L}}=107$ year instead of 94 year, analogous to a reduction in $f f$.

Up to now, calculations have been done using the assumption $\tau_{x x}^{\prime}=0$. In run $7, \tau_{x x}^{\prime}(x)$ is calculated by means of the method developed by Van der Veen (1987). The flow parameters $f_{1}$ and $f_{2}$ were the same as those used in the standard run. It appears that, again, the calculation of $\tau_{x x}^{\prime}$ hardly affects the simulation. The ice-thickness and velocity profiles, and the response times (see Table 2), are very similar to those found if $\tau_{x x}^{\prime}=0$. So, the calculation of $\tau_{x x}^{\prime}$ will have no effect on the modelled glacier response and, as it is a somewhat computer-time-consuming calculation, it is omitted from now on. The calculated stress distribution for $\tau_{x x}^{\prime} \neq 0$ has been discussed by Greuell (1989).

Finally, some experiments have been undertaken to examine the response to different extra mass-balance anomalies. It appeared that the response times are hardly affected by the magnitude of the extra mass-balance anomaly, nor whether the anomaly is applied to only the ablation or the accumulation areas.

The main conclusion from this section is that the response times of the glacier are hardly sensitive to the uncertainties and assumptions in the flow model. Strictly speaking, the conclusion only applies to the simple stepshaped forcing function used here. However, it seems reasonable to assume that it is also true for a slowly varying forcing. So, the response to climatic variations with a time-scale of the order of (or larger than) the response time of the glacier can adequately be described by the flow model. Admittedly, the procedures to calculate $p$ and $\tau^{\prime} x x$ are crude but it seems unlikely that refinements would alter the main conclusion.

\section{THE MASS BALANCE AND ITS RELATION WITH CLIMATE}

The mass balances of Hintereisferner (including Langtaufererjochferner) and Kesselwandferner have been measured by the glaciological (direct) method since 1952 and 1957, respectively. An extensive treatment of the mass-balance series of Hintereisferner for the period 195368 was presented by Hoinkes (1970).

Kuhn (1984) studied the inter-annual variation of the mass-balance-altitude profiles for Hintereisferner. $\mathrm{He}$ found that the annual profiles $(m(z, t))$ could reasonably well be described as the sum of a reference profile $\left(m^{0}(z)\right)$ and an annual anomaly $(d m(t))$ that does not depend on altitude (see Fig. 10). This representation of mass-balance fluctuations is adapted here (Equation (13)). The same equation is used for Langtaufererjochferner, whereas for Kesselwandferner another reference profile (see Fig. 10) is taken, but using the same $d m$.

The reference profiles are taken as the mean of the profiles for the "reference period" 1966-81. This period was chosen because it spans 15 years for which the annual profiles from both Hintereisferner and Kesselwandferner were available, so that a comparison of the reference profiles of the two glaciers could be made. For Hintereisferner, this is characterized by a somewhat

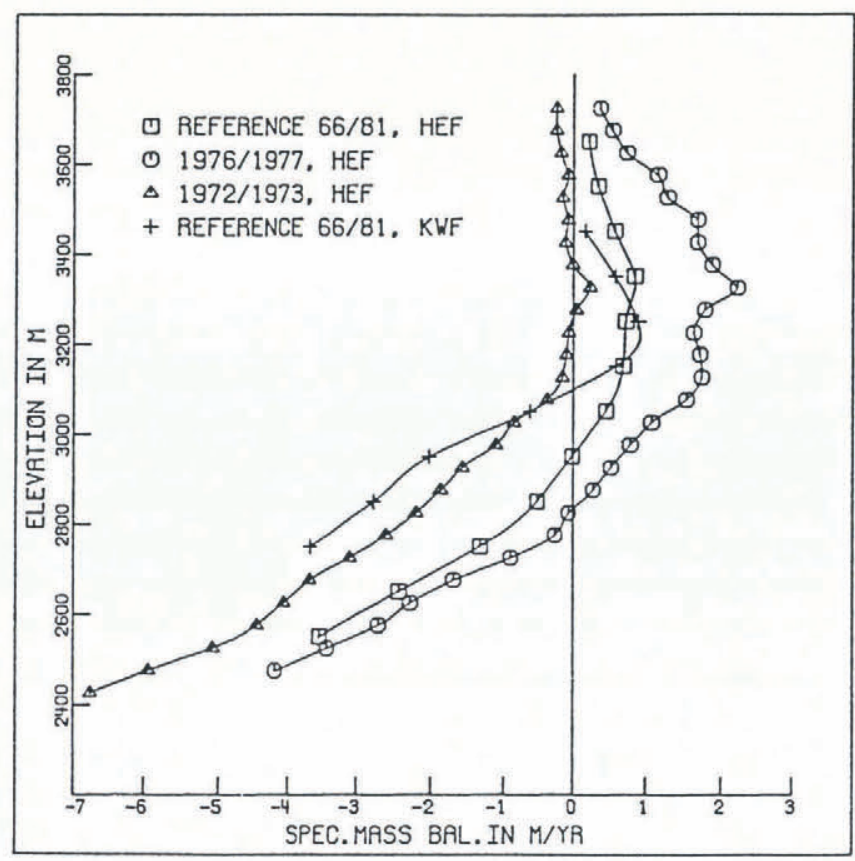

Fig. 10. Mass-balance-elevation profiles. The reference profiles (mean 1966-81) for Hintereisferner and Kesselwandferner are given together with profiles for Hintereisferner for years with extremely positive and extremely negative mass balance.

constant mass-balance gradient below $2800 \mathrm{~m}$ of about $110 \mathrm{~cm}$ w.e. year ${ }^{-1}$ per $100 \mathrm{~m}$. Higher up, the mass-balance gradient decreases with elevation. Above $3400 \mathrm{~m}$, mass balance even decreases with elevation, probably due to avalanche and wind transport of snow. The ELA (equilibrium-line altitude) of the reference profile is close to $2950 \mathrm{~m}$. Apparently, below about $3100 \mathrm{~m}$ the mass balance of Kesselwandferner is much smaller than that of Hintereisferner. The difference can certainly be partly explained by the difference in exposure (east-northeast for Hintereisferner and south-southeast for Kesselwandferner).

The details of the mass-balance distribution over the whole surface are certainly not exactly reproduced in the model. This probably does not affect the simulations in a significant way. However, "observed" and "calculated" total mass balance (the annual mass gain or loss of the whole glacier) should be equal. Here, "observed" means directly calculated from the measurements and "calculated" means calculated from the model. This point was checked for the reference period. Without any tuning, the "observed" and "calculated" values were indeed the same, both for the system Hintereisferner plus Langtaufererjochferner and for Kesselwandferner alone. This is an indication that the parameterizations of both the valley geometry and the mass balance are sufficiently accurate in the model.

In order to obtain the annual anomaly, the values of the specific mass balance from the eight height intervals between 2700 and $3500 \mathrm{~m}$ were taken. These were averaged to obtain a representative value of the annual mass balance. Then, a time average over the reference period was computed and subtracted from the annual values. Spatial means were not taken over the whole glacier, because the changing length of the glacier would 
then affect the result, whereas only climatic variations should do so. Anomalies of Hintereisferner and Kesselwandferner calculated this way have a correlation coefficient of only 0.72 . It is beyond the scope of this study to discuss the possible causes of this relatively low correlation. Assuming that the measurements on Hintereisferner are more accurate, the mass-balance anomaly of Hintereisferner was also used for Kesselwandferner.

For the reconstruction of the mass-balance history, a relation was needed between basic climatological variables and the annual mass-balance anomaly $(\mathrm{dm})$. A multiple linear regression analysis was performed with the data from Vent, a village about $10 \mathrm{~km}$ northeast of the glacier. This has been done before (Wakonigg, 1971; Hoinkes and Steinacker, 1975, Günther and Widlewski, 1986). It was felt that mean temperature $\left(T_{\mathrm{abl}}\right)$, solid precipitation $\left(s_{\mathrm{abl}}\right.$ and $\left.s_{\text {acc }}\right)$ and mean cloudiness $\left(n_{\mathrm{abl}}\right)$ would be the most appropriate climatological variables. The subscripts abl and acc refer to the ablation and accumulation seasons, respectively. The mean for the ablation season is defined here as the mean of the values for May, June, July, August and September, where the values for May and September are weighted by a factor of 0.5 . The accumulation-season mean comprises the values for the other months of the year and half the values for May and September.

The variables $s_{\mathrm{abl}}$ and $s_{\mathrm{acc}}$ are separated because snow falling in the ablation season has a double effect on the mass balance; it contributes directly to the accumulation but, moreover, it increases the albedo and consequently decreases the ablation (see Greuell and Oerlemans, 1986). This second effect is of lesser importance for snow falling during the accumulation season. Solid precipitation was estimated from the mean monthly temperature $\left(T_{\mathrm{i}}\right)$ and the monthly total precipitation $\left(p_{\mathrm{i}}\right)$ in Vent (see Greuell, 1989).

The resulting equation reads:

$$
d m=157.6-40.7 T_{\mathrm{abl}}+3.9 s_{\mathrm{acc}}+3.2 s_{\mathrm{abl}}
$$

where $d m, s_{\text {acc }}$ and $s_{\text {abl }}$ are in cm w.e. year ${ }^{-1}$ and $T_{\text {abl }}$ is in ${ }^{\circ} \mathrm{C}$. With $r=0.85,72.5 \%$ of the variance is explained.

Taking into account $n_{\mathrm{abl}}$ does not increase the variance explained. This is amazing, because the radiative components that are largely affected by cloudiness are dominant in the energy budget (see, for example, Greuell and Oerlemans, 1989). The high correlation coefficient (0.91) between the cloudiness data and data for sunshine duration indicates that the cloudiness data are reliable. So, another explanation must be found. A hint has been given by Müller (1984). Increased cloudiness always decreases the net shortwave radiation and increases the net longwave radiation. In most cases, the effect is such that net radiation decreases but, for high albedos $(>0.7)$, which indeed may occur on glaciers, the effect is reversed. Detailed energy-balance calculations should shed light on this.

\section{GLIMATE AND MASS-BALANGE RECON- STRUCTION}

\subsection{Introduction}

As we wish to simulate the 1855 maximum stand, the
Table 3. Overview of the series used for the climatic reconstruction for Vent

Temperature

Precipitation

VENT 1

VENT 2

$\begin{array}{ccc}\begin{array}{c}1755-1858 \\ \text { Basel }\end{array} & \begin{array}{c}1755-1857 \\ \text { Mean of regional } \\ \text { average 1858-1921 }\end{array} & \begin{array}{c}1755-1890 \\ \text { Mean of VENT 2 } \\ 1891-1910\end{array} \\ 1859-99 & \begin{array}{c}1858-1947 \\ \text { Innsbruck }\end{array} & \begin{array}{c}\text { Regional average } \\ \text { 1900-82 }\end{array} \\ \text { Vent } & 1948-82 & 1891-1982 \\ \text { Vent } & \text { Vent } \\ 1983-85 & \text { 1983-85 } & 1983-85 \\ \text { Basel } & \text { Regional average } & \text { Regional average }\end{array}$

response time of the glacier (nearly 100 year) imposes that the forcing is reconstructed back to about 1750 . Unfortunately, the temperature and precipitation records from Vent are reliable only from 1900 and 1948 onwards. That is why an attempt was made to reconstruct the records for the period before with records from other stations. The start of the Basel temperature record in 1755 sets an obvious limit to the length of the reconstruction. An overview of the series used for the reconstruction of the climatic series for Vent is given in Table 3. VENT 1 and VENT 2 are forcing series based on different reconstructions of precipitation.

\subsection{Temperature}

First of all, records of the mean monthly temperature from five stations near the Alps were collected. The record from Vent (1900-82), extended with the reconstruction for 1851-99 made by Lauffer (1966) by means of the Innsbruck series, was added and 15 year running means were compared (see Fig. 11).

Apparently, the coherence is large, so that the following conclusions can be drawn:

There are no serious inhomogeneities in any of the series with the exception of the beginning of the Milan series.

The records have a high correlation coefficient on a time-scale of 15 years.

Any of the records, except for the Milan one, can be used to reconstruct the Vent record before 1859.

The Basel series was chosen for the reconstruction, because it is the longest one (starting in 1755). Monthly values were computed from 12 linear regression equations developed by using means of the common records from Vent and Basel (1859-1982). 


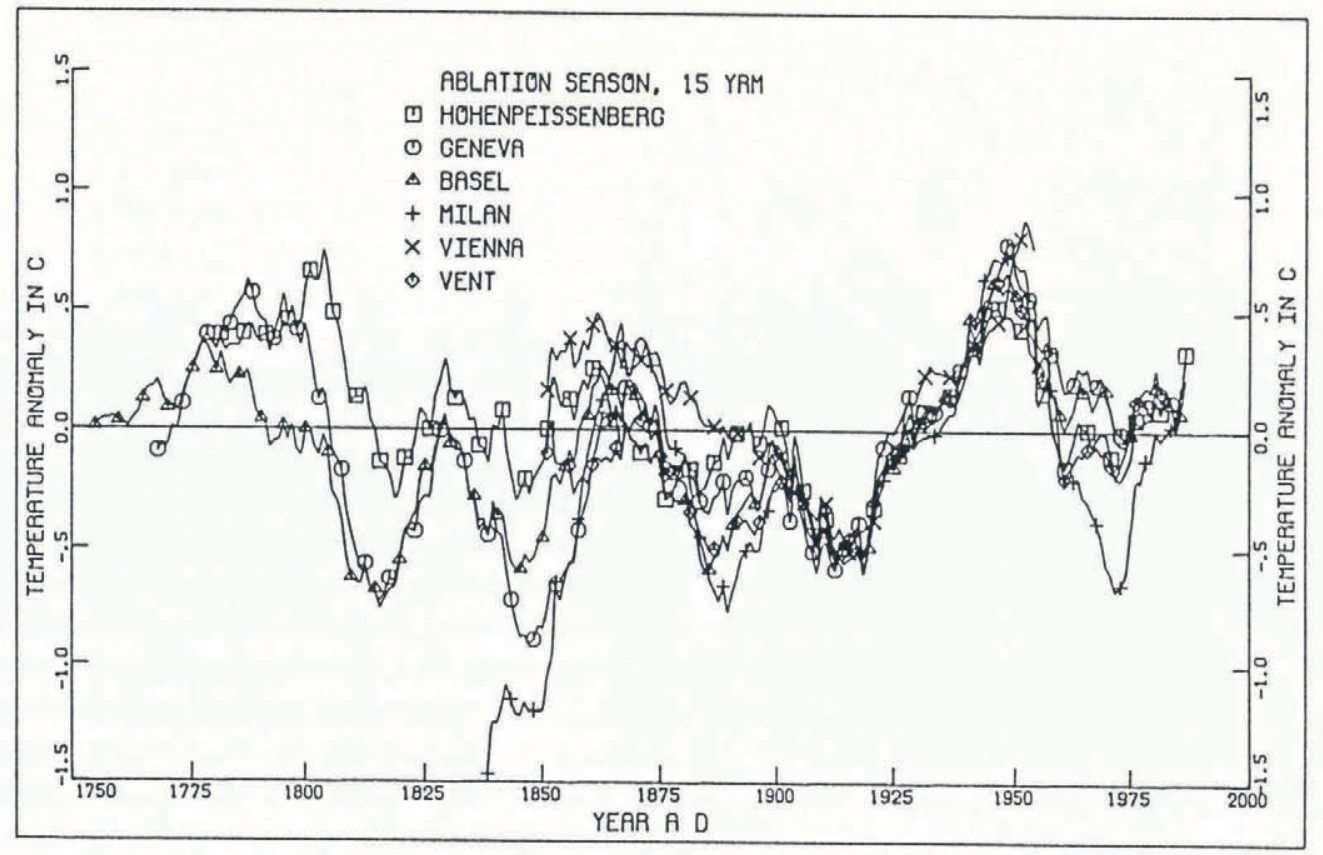

Fig. 11. Variation of the mean temperature during the ablation season in Vent and five other locations near the Alps. The anomaly is relative to the mean for 1901-50. The plot gives 15 year running means.

\subsection{Precipitation}

Reconstruction of the precipitation is more difficult. Precipitation is correlated over much shorter distances than temperature, and records are more liable to contain inhomogeneities caused by changes in surroundings and equipment. Moreover, long and well-investigated records are scarce.

As with the temperature, five records from stations in and near the Alps were compared. They appeared to have hardly any coherence. Therefore, records from stations situated nearer to Vent were collected. Ten records were found within a distance of $100 \mathrm{~km}$ (eight are within $40 \mathrm{~km}$ ). These were examined for the presence of inhomogeneities and those records and parts of records believed to be reliable were selected to form a Regional Average Series (RAS) (see Greuell, 1989). When 15 year running means are compared, the coherence between the selected parts of the individual series and the RAS appears to be large. So, on a time-scale of 15 years, precipitation fluctuations are coherent within the region considered and it was concluded that the RAS can be used to reconstruct the precipitation at Vent.

In 1948, the station at Vent was displaced from one end of the village to the other. This showed up as an inhomogeneity in the precipitation series. Therefore, the RAS was used until this time, although the Vent series started in 1891 . The reliability of the RAS depends to a great extent on the number of records composing it. Before 1891, we have only two records. So, the reliability of the early part is poor. For 1755-1857, no precipitation data are available. It was assumed that the annual precipitation during this period was equal to the average annual precipitation during the first half of the RAS (1858-1920). There is no reason for this assumption.

In order to obtain an indication of the range of uncertainty, a second precipitation series was composed
(VENT 2). It consists of the Vent series for 1891-1982, and for 1755-1890; the annual amount of precipitation was assumed equal to the mean annual amount of precipitation for 1891-1910 at Vent. So, this series ignores the 1948-inhomogeneity.

\subsection{Mass balance}

The temperature and precipitation series were now converted to a forcing series for the flow model by means of Equation (14) (see Fig. 12). All maxima and minima occurring in the total forcing also can easily be recognized in the temperature part of the forcing.

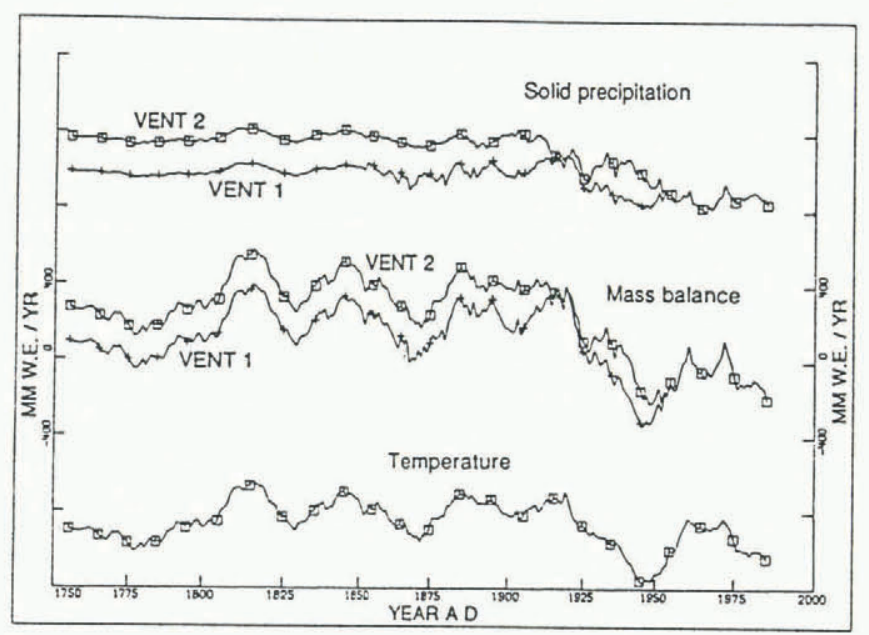

Fig. 12. Two reconstructions of the mass-balance anomaly $(d m)$. Parts of the mass-balance variations due to variations of annual solid precipitation and temperature during the ablation season are also shown separately. Notice that maxima in the "temperature curve" correspond to minima in $T_{\mathrm{abl}}$. 


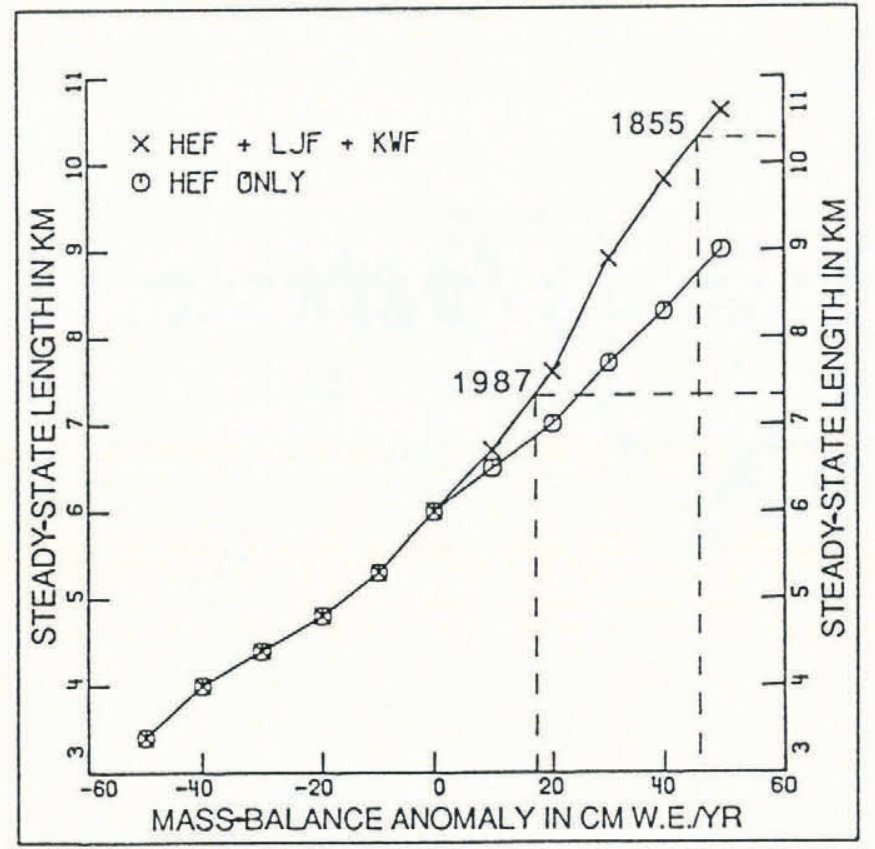

Fig. 13. Steady-state length of Hintereisferner as a function of the mass-balance anomaly. In the calculations corresponding to the upper curve, the fluxes from Langtaufererjochferner and Kesselwandferner were taken into account; for the lower curve these fluxes were neglected. The 1855 maximum stand and the 1987 length are indicated.

Apparently, the temperature part is dominant. Note that this is trivial for the period before 1858 when total precipitation was assumed to be constant.

\section{THE SIMULATIONS}

Before starting with the historical simulations, we shall first study the relation between a fixed mass-balance anomaly and the steady-state length (Fig. 13). The difference between the two curves (with and without tributaries) is so large that one has to conclude that modelling of the tributaries is crucial. Hintereisferner seems to be very sensitive to changes in $d m$ : a difference of $100 \mathrm{~cm}$ w.e. year ${ }^{-1}$ results in a length difference of $7.2 \mathrm{~km}$. In the figure, the mass-balance anomalies corresponding to the 1855 and 1987 lengths are indicated. Note that, if the reference mass balance (mean 1966-81) persists, the glacier will ultimately reach a steady-state length of $6 \mathrm{~km}$.

For the first simulation, VENT 1 was imposed as forcing and the simulation started in 1755. As an initial profile, the steady-state profile corresponding to the average mass-balance anomaly during the first 50 years of the run $\left(10 \mathrm{~cm}\right.$ w.e. year $\left.{ }^{-1}\right)$ was taken. The result is disappointing (Fig. 14). The maximum length is only $7.4 \mathrm{~km}$ and it is reached almost a century too late. The curves giving the steady-state length may help in interpreting the calculations. To construct them, the 15 year running means of the mass-balance anomaly series were translated into the corresponding (see Fig. 13) series of steady-state lengths. Thus, these curves represent the forcing. At any particular moment the steady-state length is the length towards which the simulated glacier tends to grow or shrink. In the simulation before 1910, the steady-state length is always much smaller than the observed length. This demonstrates that the failure must be attributed to the mass-balance reconstruction and cannot be due to inadequacies in the flow model. It has already been argued that the mass-balance reconstruction becomes unreliable before around 1900 .

While VENT 1 before 1900 has an average value of $15-20 \mathrm{~cm}$ w.e. year ${ }^{-1}$, it is estimated that an average value of $40-50 \mathrm{~cm}$ w.e. year $^{-1}$ would be necessary to explain the 1770 and 1855 maxima. The difference of about

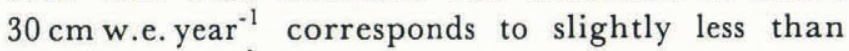
$10 \mathrm{~cm}$ w.e. year ${ }^{-1}$ of solid precipitation in Vent or alternatively to a temperature difference of about $0.75^{\circ} \mathrm{C}$. Whether such corrections are feasible depends on the errors in the climatic reconstructions. The error in the temperature seems to be $0.2-0.3^{\circ} \mathrm{C}$ at most (see Fig. 11) but it is difficult to estimate the error in the precipitation. However, $10 \mathrm{~cm}$ w.e. year ${ }^{-1}$ of solid precipitation seems to be a large amount compared to the mean annual total precipitation of $69.2 \mathrm{~cm}$.

In order to eliminate the unreliable part of the forcing,

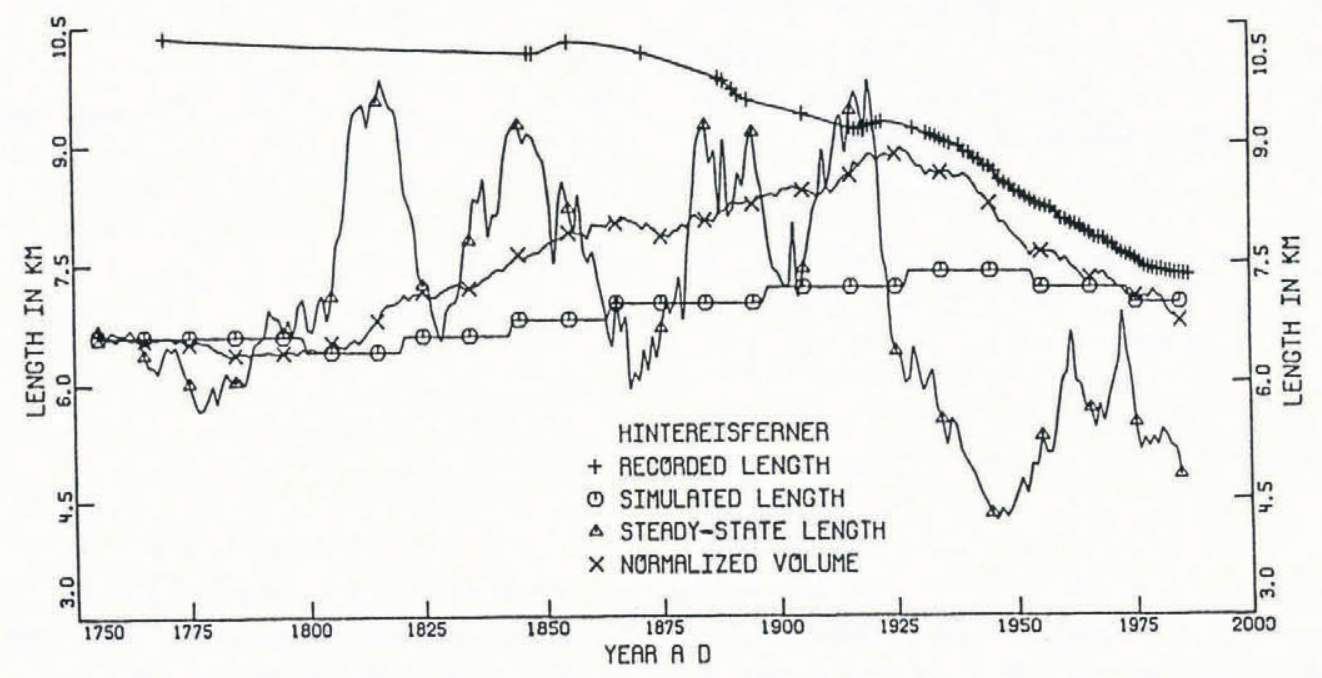

Fig. 14. Simulation with VENT 1 from 1775 to 1985 for the main stream. 


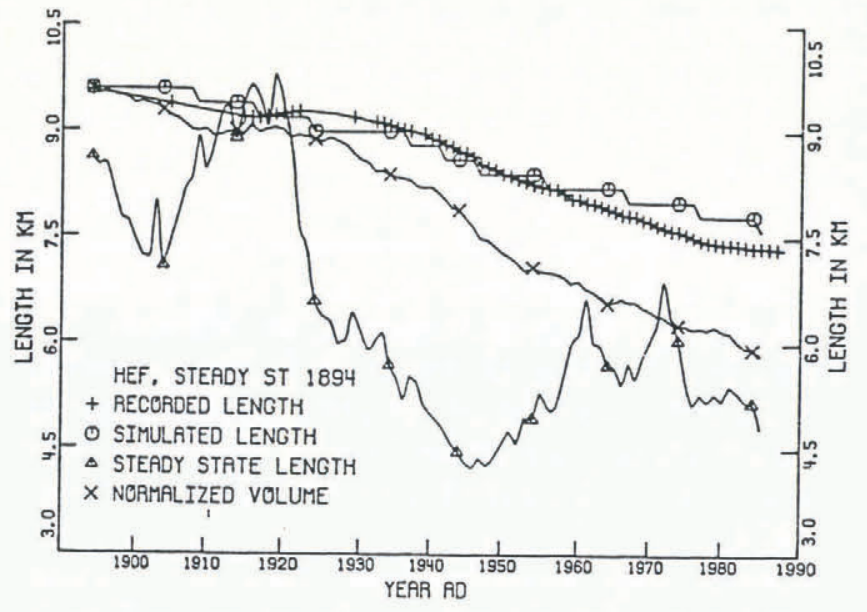

Fig. 15. Simulation with VENT 1 from 1894 to 1985 for the main stream ( $a$ ) and Kesselwandferner (b). Volume and flux (into the main stream) are calculated and normalized by their initial values.

an attempt will be made to simulate the historical front variations using VENT 1 from 1894 onward, when a map was drawn by Blümcke and Hess (1899). As an initial geometry, the steady-state profile with the length in 1894 $(9.5 \mathrm{~km})$ was taken. This corresponds to $d m$ $=40 \mathrm{~cm}$ w.e. year ${ }^{-1}$.

The result of the run is depicted in Figure 15. The observed total retreat of the main stream between 1894 and 1985 was about $2.2 \mathrm{~km}$, while a retreat of $2.0 \mathrm{~km}$ is calculated by the model. This is a satisfactory result.

Between 1915 and 1920, a maximum appears in the forcing, resulting in a slightly increasing volume. Presumably, this is related to the small advance $(85 \mathrm{~m})$ around 1920, which does not appear in the calculations. Two points may be advanced to explain this: (a) the advance is smaller than the grid-point distance $(200 \mathrm{~m})$, and (b) the advance was caused by an abnormal increase in ice velocity that must be interpreted as a "mini-surge" (personal communication from R. van de Wal). Such a phenomenon cannot be simulated by the present model.

The simulation of the length variations of Kesselwandferner is unsatisfactory. According to the observations, the retreat after 1922 was interrupted by an advance between 1965 and 1983 of about $300 \mathrm{~m}$. The calculated retreat is slower than the observed one and it is not interrupted by an advance. The mismatch may partly be due to the use of the mass-balance anomaly of Hintereisferner for Kesselwandferner. Moreover, Kesselwandferner terminated in an icefall on a relatively steep slope since it decoupled from Hintereisferner and the dynamics of the steep parts of glaciers is not so well simulated by the model. The flux of ice into the main stream corresponds in a crude way to the observed frontal variations.

\section{CONGLUSIONS AND DISGUSSION}

The aim of the present study was to simulate the historical frontal variations of Hintereisferner. In a model run covering the period 1894-1985 the total retreat was almost correctly computed (error of $10 \%$ ). This gives some confidence in the model. However, a calculation starting in 1755 failed completely. This must be due to an inadequate reconstruction of the mass-balance history.

Fluctuations in the mass balance were related to fluctuations in climatic elements by a multiple linearregression analysis. On the climatic side, the temperature during the ablation period and the annual precipitation appeared to be the decisive elements. Although the reconstruction of the temperature back to 1755 seems to be quite accurate, this cannot be said about the precipitation. For the period before 1858, no precipitation series from the region around Hintereisferner is available at all. Until 1900, series are scarce so that a reconstruction of the precipitation is unreliable. This poses an obvious obstacle to the simulations. Inadequacies in the description of any of the other model elements probably have a smaller effect.

Progress relative to previous, similar studies can be summarized in two points. First, the mass balance is reconstructed more carefully. Specifically the following points have been improved:

\section{Checking the climate series on inhomogeneities.}

Checking whether climate series from other locations can be used to reconstruct the local climate.

Relating the climatic fluctuations to mass-balance fluctuations in a fixed altitudinal interval, and not to the mean specific mass balance of the glacier which depends on the area/altitude distribution.

Not tuning the mass-balance variations with the resulting length variations. Here the mass balance is determined only by mass-balance and climatic data.

Secondly, it has been shown that uncertainties and assumptions in the flow model hardly affect the glacier response to climatic fluctuations with a time-scale of the order of (or greater than) the response time of the glacier (around 100 year). However, shorter-term fluctuations are problematic, e.g. the 1920 advance did not show up in the sir.ulations. In this special case there are two obvious reasors: it was a sub-grid phenomenon and it was caused by some kind of surge which the model cannot simulate. More so, in general, the dynamics of the snout play a relıtively important role in these short-term fluctuations. Ac the snout, the force budget becomes more complicated than elsewhere, and the model used here certainly does not simulate its dynamics well. Probably, the present flow model is less suitable for the simulation of glaciers with a complicated geometry. In the model only the shear stress is taken into account, while other stresses become important near icefalls, in parts of the valley where the width varies strongly, etc. This might be the reason for the failure of the calculations for Kesselwandferner which currently ends in an icefall.

\section{ACKNOWLEDGEMENTS}

The investigations described in this paper were conducted 
while I was a Ph.D. student at the Institute of Meteorology and Oceanography of the State University of Utrecht. I am grateful to my supervisor, H. Oerlemans, to $R$. van de Wal and $H$. Blatter for discussing the simulations with me and for their comments on earlier versions of this paper. I should like to thank M. Kuhn for sending me the unpublished ice-velocity, ice-thickness and climatic data, and G. Patzelt for the observed length variations. I am also indebted to numerous people who helped me to collect the climatic series. This research was funded by the Dutch Ministry of Housing, Physical Planning and Environment (VROM) and the Netherlands Organization for Scientific Research (NWO).

\section{REFERENCES}

Beschel, R. 1950. Flechten als Altersmassstab rezenter Moränen. Z. Gletscherkd. Glazialgeol., 1(2), 152-161.

Bindschadler, R. 1983. The importance of pressurized subglacial water in separation and sliding at the glacier bed. F. Glaciol., 29(101), 3-19.

Blümcke, A. and H. Hess. 1899. Untersuchungen am Hintereisferner. Zeitschrift des Deutschen und Österreichischen Alpenvereins. 2. Wissenschaftliche Ergänzungsheft.

Greuell, W. 1989. Glaciers and climate. (Ph.D. thesis, Rijksuniversiteit Utrecht. Instituut voor Meteorologie en Fysische Oceanografie.)

Greuell, W. and J. Oerlemans. 1986. Sensitivity studies with a mass balance model including temperature profile calculations inside the glacier. Z. Gletscherkd. Glazialgeol., 22(2), 101-124.

Greuell, W. and J. Oerlemans. 1989. Energy balance calculations on and near Hintereisferner (Austria) and an estimate of the effect of greenhouse warming on ablation. In Oerlemans, J., ed. Glacier fluctuations and climatic change. Dordrecht, etc., Kluwer Academic Publishers, 305-323.

Günther, R. and D. Widlewski. 1986. Die Korrelation verschiedener Klimaelemente mit dem Massenhaushalt alpiner und skandinavischer Gletscher. $Z$. Gletscherkd. Glazialgeol., 22(2), 125-147.

Hodge, S. M. 1979. Direct measurement of basal water pressure: progress and problems. 7. Glaciol., 23(89), 309-319.

Hoinkes, H. 1970. Methoden und Möglichkeiten von Massenhaushaltsstudien auf Gletschern. Z. Gletscherkd. Glazialgeol., 6(1-2), 37-90.

Hoinkes, H. and R. Steinacker. 1975. Zur Parametrisierung der Beziehung Klima-Gletscher. Riv. Ital. Geofis. Scienze Affini, 1, 97-104.

Huybrechts, P., P. de Nooze and H. Decleir. 1989. Numerical modelling of Glacier d'Argentière and its historic front variations. In Oerlemans, J., ed. Glacier fluctuations and climatic change. Dordrecht, etc., Kluwer
Academic Publishers, 373-389.

Kuhn, M. 1984. Mass budget imbalances as criterion for a climatic classification of glaciers. Geogr. Ann., 66A(3), 229-238.

Kuhn, M., G. Markl, G. Kaser, U. Nickus, F. Obleitner and H. Schneider. 1985. Fluctuations of climate and mass balance: different responses of two adjacent glaciers. Z. Gletscherkd. Glazialgeol., 21, 409-416.

Kuhn, M., G. Kaser, G. Markl, H.P. Wagner and H. Schneider. Unpublished. 25 Jahre Massenhaushaltsuntersuchungen am Hintereisferner. Institut für Meteorologie und Geophysik der Universität Innsbruck, 1979.

Lauffer, I. 1966. Das Klima von Vent. (Ph.D. thesis, Institut für Meteorologie und Geophysik der Universität Innsbruck.)

Müller, H. 1984. Zum Strahlungshaushalt im Alpenraum. Eidg. Tech. Hochschule, Zürich. Versuchsanst. Wasserbau, Hydrol. Glaziol. Mitt. 71.

Nye, J.F. 1965. The flow of a glacier in a channel of rectangular, elliptic or parabolic cross-section. $\mathcal{J}$. Glaciol., 5(41), 661-690.

Oerlemans, J. 1986. An attempt to simulate historic front variations of Nigardsbreen, Norway. Theor. Appl. Climatol., 37, 126-135.

Oerlemans, J. 1988. Simulation of historic glacier variations with a simple climate-glacier model. $\mathcal{J}$. Glaciol., 34(118), 333-341.

Paterson, W.S.B. 1981. The physics of glaciers. Second edition. Oxford, etc., Pergamon Press.

Patzelt, G. 1985. The period of glacier advances in the Alps, 1965 to 1980. Z. Gletscherkd. Glazialgeol., 21, 403407.

Porter, S. C. 1986. Pattern and forcing of Northern Hemisphere glacier variations during the last millennium. Quat. Res., 26(1), 27-48.

Röthlisberger, H. 1972. Water pressure in intra- and subglacial channels. f. Glaciol., 11(62), 177-203.

Stroeven, A., R. van de Wal and J. Oerlemans. 1989. Historic front variations of the Rhône Glacier: simulation with an ice flow model. In Oerlemans, J., ed. Glacier fluctuations and climatic change. Dordrecht, etc., Kluwer Academic Publishers, 391-405.

Van der Veen, C.J. 1987. Longitudinal stresses and basal sliding: a comparative study. In Van der Veen, C.J. and J. Oerlemans, eds. Dynamics of the West Antarctic ice sheet. Dordrecht, etc., Kluwer Academic Publishers, 223-248.

Wakonigg, H. 1971. Gletscherverhalten und Witterung. Z. Gletscherkd. Glazialgeol., 7(1-2), 103-123.

Wilhelm, F. 1975. Schnee- und Gletscherkunde. Walter de Gruyter.

The accuracy of references in the text and in this list is the responsibility of the author, to whom queries should be addressed. 